\title{
Solid State Bioconversion for Producing Common Bean (Phaseolus vulgaris L.) Functional Flour with High Antioxidant Activity and Antihypertensive Potential
}

\author{
Maria Lilia Guzmán-Uriarte ${ }^{1}$, Luis Martín Sánchez-Magaña ${ }^{2}$, Graciela Yaneth Angulo-Meza ${ }^{1}$, \\ Edith Oliva Cuevas-Rodríguez ${ }^{2}$, Roberto Gutiérrez-Dorado ${ }^{1,2}$, Saraid Mora-Rochín ${ }^{2}$, \\ Jorge Milán-Carrillo ${ }^{1,2}$, Angel Valdez-Ortiz ${ }^{1,2}$, Cuauhtémoc Reyes-Moreno ${ }^{1,2^{*}}$ \\ ${ }^{1}$ Faculty of Chemical-Biological Sciences, Autonomous University of Sinaloa, Culiacán, Mexico; ${ }^{2}$ Northwest Regional Program for \\ Doctorate in Biotechnology, Autonomous University of Sinaloa, Culiacán, Mexico. \\ Email: *creyes@uas.uasnet.mx
}

Received January $4^{\text {th }}, 2013$; revised February $21^{\text {st }}, 2013$; accepted March $2^{\text {nd }}, 2013$

Copyright (C) 2013 Maria Lilia Guzmán-Uriarte et al. This is an open access article distributed under the Creative Commons Attribution License, which permits unrestricted use, distribution, and reproduction in any medium, provided the original work is properly cited.

\begin{abstract}
The main objective of this investigation was to study the time effect during solid state bioconversion (SSB) on total phenolics content $(T P C)$ and antioxidant activity (AoxA) of common beans to improve antihypertensive functionality. Cooked cotyledons of dehulled common beans were inoculated with a suspension of R. oligosporus NRRL 2710 (1 $\times$ $10^{6}$ spores $/ \mathrm{mL}$ ), and incubated at $35^{\circ} \mathrm{C}$ for times of $24,36,48,60,72,84,96$ and $108 \mathrm{~h}$ (after $108 \mathrm{~h}$ the cotyledons showed off odor). Flours from bioprocessed dehulled common bean from each incubation time were blended with their corresponding milled seed coats. The best time for producing bioprocessed common bean (added with seed coats) functional flour with the highest $A o x A(O R A C$ value $=17,468 \mu$ mol Trolox equivalents (TE)/100 g sample, dw; $A B T S$ value $=13,505 \mu \mathrm{mol} \mathrm{TE} / 100 \mathrm{~g}$ sample, $\mathrm{dw}$ ) was $108 \mathrm{~h}$. The SSB process substantially increased TPC and total hydrophilic Aox $A$ and antihypertensive potential of common beans in 2.24, $2.45-2.73$ and 6769 times, respectively. Proteins hydrolyzates from unprocessed whole and bioprocessed $(108 \mathrm{~h})$ common beans had $\mathrm{IC}_{50}$ [concentration needed to inhibit $50 \%$ the activity of angiotensin converting enzyme (ACE)] of 79.2 and $0.0117 \mu \mathrm{g} / \mathrm{mL}$, respectively. The SSB is an efective strategy to improve the TPC of common beans for enhanced functionality with improved antioxidant activity and antihypertensive potential.
\end{abstract}

Keywords: Solid State Bioconversion; Common Bean Functional Flour; Antioxidant Activity; Antihypertensive Activity

\section{Introduction}

Phenolic compounds and antioxidant activities in legume seeds were reported by several earlier communications, although legumes constitute one of the most abundant and least expensive sources of protein in human/animal diet [1]. Among natural antioxidants, phenolics form the largest group. Such compounds are secondary metabolites synthesised solely in plants. Phenolics comprise several groups of compounds differing in structure: phenolic acids (benzoic acids and hydroxycinnamic acids), flavonoids (flavonols, flavones, flavanols, isoflavones), stilbenes and tannins [2-4]. The raw materials that are

${ }^{*}$ Corresponding author. rich in antioxidants include dry beans of Phaseolus vulgaris L. which, among other components, contain flavonoids and phenolic acids [5-7]. A high consumption of beans is believed to reduce the incidence of cardiac diseases, diabetes, colon cancer and hypertension [8-11]. It has been reported that many natural angiotensin converting enzyme (ACE) inhibitors isolated from the hydrolysis of various grains proteins such soybean [12], and common beans [13] or during gastrointestinal digestion or food processing [14,15] can be used as pharmaceuticals and physiological functional food supplements for hypertension therapy.

Solid state bioconversion (SSB) is microbial bioprocessing of a solid food substrate that acts as a physical 
support and source of nutrients in the presence of low free liquid [16]. It is a simple alternative technology with a long history in Asia to improve the nutritional quality and palatable characteristics of cereals and legumes. Tempeh is a nutritious oriental bioprocessed food produced by SSB of soybeans with Rhizopus oligosporus. Several other substrates have been used to prepare tempeh, e.g. common beans, chickpeas, rice, oat, lupine, home bean, ground nut, wheat, corn/soybean [17-21]. The solid state bioconversion (SSB) would increase the phenolic content and antioxidant activity of fungal processed seeds and legumes which will enhance the potential health-relevant functionality [22-24].

The objective of this investigation was to study the effect of fermentation time during solid state bioconversion (SSB) on total phenolic content and antioxidant activity of common beans to improve antihypertensive functionality.

\section{Materials and Methods}

\subsection{Chemicals}

Reagents Folin-Ciocalteu reagent, dichlorofluorescin diacetate, 2,2'-Azobis (2-amidinopropane), ABTS (2,2'azinobis-(3-ethylbenthiazoline-6-sulfonic acid) diammonium salt, ACE (from rabbit lung), hippuryl-histidylleucine, pancreatin enzyme, potassium persulfate (dipotassium peroxdisulfate), PBS (phosphate buffered saline), gallic acid, trolox, $\mathrm{HCl}$, ethanol, acetic acid, were purchased from Sigma Aldrich Chemicals (St Louis, MO, USA). All other chemical and reagents were of analytical grade.

\subsection{Legumes}

Common beans (Phaseolus vulgaris L., var Azufrado Higuera) were cultivated at the Culiacan Valley Experimental Station of the National Research Institute for Forestry, Agriculture and Livestock (INIFAP), Sinaloa, México. Grains were harvested, cleaned and stored at $4^{\circ} \mathrm{C}$ in tightly sealed containers until used. The Rhizopus oligosporus NRRL 2710 strain was obtained from American Type Culture Collection, Manassas, USA.

\subsection{Manufacture of Bioprocessed Common Bean Flours (BCBF)}

Bioprocessed common bean flours were prepared using the procedure described by Reyes-Moreno et al. [25] with minor modifications. Common bean seeds were soaked at $25^{\circ} \mathrm{C}$ for $16 \mathrm{~h}$ in acetic acid solution (pH 3.0). Seeds were then drained and their seed coats removed manually. Seed coats were dried (moisture content 11\%) and milled (UD, Cyclone Sample Mill, UD Corp, Boul- der, CO, USA) to pass through and 80-US mesh ( 0.180 $\mathrm{mm})$ screen, packed and stored $\left(4^{\circ} \mathrm{C}\right)$. The cotyledons were cooked in acetic acid solution $(\mathrm{pH} 3.0)$ at $90^{\circ} \mathrm{C}$ for $30 \mathrm{~min}$, cooled at $25^{\circ} \mathrm{C}$ for $3 \mathrm{~h}$, inoculated with a suspension of $R$. oligosporus NRRL $2710\left(1 \times 10^{6}\right.$ spores $\left./ \mathrm{mL}\right)$, and packed in perforated polyethylene bags $(15 \times 15 \mathrm{~cm})$. Solid state bioconversion (SSB) was performed at $35^{\circ} \mathrm{C}$ and fermentation times of 24, 36, 48, 60, 72, 84, 96 and $108 \mathrm{~h}$. The resulting bioprocessed common bean cotyledons were dried $\left(50^{\circ} \mathrm{C} / 8 \mathrm{~h}\right)$, cooled $\left(25^{\circ} \mathrm{C}\right)$ and milled $(80$-US mesh $=0.180 \mathrm{~mm})$. Bioprocessed common bean flours from each fermentation time were blended with their corresponding milled seed coats, packed and kept at $4^{\circ} \mathrm{C}$ in tightly sealed containers until use.

\subsection{Extraction of Free Phenolic Compounds}

Free phenolic compounds in ground samples were extracted as previously reported by Dewanto et al. [26] with minor modifications. Briefly, $1 \mathrm{~g}$ of ground sample was blended with $10 \mathrm{~mL}$ of $80 \%$ chilled ethanol for 10 $\mathrm{min}$ and then centrifugated at $2500 \mathrm{~g}$ for $10 \mathrm{~min}$, the supernatant was concentrated under vacuum at $45^{\circ} \mathrm{C}$. The resulting extracts were stored at $-40^{\circ} \mathrm{C}$ until evaluation.

\subsection{Extraction of Bound Phenolic Compounds}

Bound phenolic compounds in ground samples were extracted using the method reported by Adom \& Liu [27] with minor modifications of Mora-Rochín et al. [28]. After extraction of free phenolic compounds, the residue was digested with $10 \mathrm{~mL}$ of $2 \mathrm{M}$ sodium hydroxide in a water bath at $95^{\circ} \mathrm{C}$ for $30 \mathrm{~min}$ with previous removal of $\mathrm{O}_{2}$ using nitrogen gas. Finally, the sample was agitated for 1 additional hour at $25^{\circ} \mathrm{C}$ (In the original technique of Adom and Liu [27] the residue was digested only at room temperature for $1 \mathrm{~h}$ ). The mixture was acidified $(\mathrm{pH}<2.0)$ with $2 \mathrm{~mL}$ of $2 \mathrm{M}$ hydrochloric acid and extracted with hexane to remove lipids. The final solution was extracted five times with $10 \mathrm{~mL}$ of ethyl acetate for each extraction. The ethyl acetate fraction was pooled and evaporated to dryness under vacuum at $35^{\circ} \mathrm{C}$. Bound phenolic compounds were reconstituted in $2 \mathrm{~mL}$ of methanol-water $(50: 50, \mathrm{v} / \mathrm{v})$ to improve the solubility of the compounds and have a clear and homogeneous solution. The extracts were frozen and stored at $-40^{\circ} \mathrm{C}$ until evaluation.

\subsection{Determination of Total Phenolics}

Phenolic content of free and bound phenolic compounds extracts were determined using the colorimetric method described by Singleton et al. [29]. Briefly, $20 \mu \mathrm{L}$ of extracts were oxidized with $180 \mathrm{~mL}$ of Folin-Ciocalteu 
reagent. After $20 \mathrm{~min}$, absorbance of the resulting blue color was measured at $750 \mathrm{~nm}$ using a Synergy Microplate Reader (Synergy $^{\mathrm{TM}}$ Multi-Detection, BioTek, Inc, Winooski, VT). A calibration curve was prepared using gallic acid as standard and total phenolics were expressed as milligrams of gallic equivalents (mg GAE) per $100 \mathrm{~g}$ of sample $(\mathrm{dw})$.

\subsection{Antioxidant Activity (AoxA)}

\subsubsection{Oxigen Radical Absorbance Capacity (ORAC) Assay}

Free and bound hydrophilic antioxidant capacities were determined using the oxygen radical absorbance capacity $(O R A C)$ assay. Extracts were evaluated against a standard of Trolox with Fluorescein as a probe as described initially by Cao et al. [30] and later modified by $\mathrm{Ou}$ et al. [31]. Peroxyl radicals were generated by 2,2-azobis (2-amidinopropane) dihydrochloride, and fluorescent loss was monitored in a Microplate Reader (SynergyTM HT Multi-Detection, BioTek, Inc., Winooski, VT, USA). The absorbance of excitation and emission was set at 485 and $538 \mathrm{~nm}$, respectively. Data was expressed as micromoles of Trolox equivalents (TE) per $100 \mathrm{~g}$ of dry weight (dw) sample.

\subsubsection{ABTS Radical Cation Decolorization Assay}

[2,2'-azinobis-(3-ethylbenthiazoline-6-sulfonic acid)] can produce stable free radicals, which are decolorized into their non-radical form when reacting with antioxidants. The method for determining ABTS radical scavenging activity was modified from Re et al. [32]. Briefly, $A B T S^{+}$ was generated by oxidation of $7 \mathrm{mM} A B T S$ with 2.45 $\mathrm{mM}$ potassium persulfate $\left(\mathrm{K}_{2} \mathrm{~S}_{2} \mathrm{O}_{8}\right)$, and then stored in a dark place at room temperature for $12-16 \mathrm{~h}$. Then $A B T S^{+}$ stock solution was diluted with deionized water to obtain $A B T S^{+}$working solution. The reactions between $A B T S^{+}$working solution and different sample concentrations were initiated and stored at room temperature until the reaction was complete. After that, the reacted samples' absorbance was read at $734 \mathrm{~nm}$. The results are expressed as $\mu \mathrm{mol}$ Trolox equivalent (TE)/100 g sample, dw.

\subsection{Antihipertensive Potential}

\subsubsection{Enzyme Hydrolysis}

BCBF with higher AoxA was hydrolysed with pancreatin enzyme (a mixture of digestive enzymes) so its action simulates gastrointestinal digestion according to Humiski \& Aluko [33] and Adler-Nissen [34]. The sample was mixed with deionized water to prepare $10 \%(\mathrm{w} / \mathrm{v})$ solutions, then temperature and $\mathrm{pH}$ was adjusted at $39^{\circ} \mathrm{C}$ and 8.0 , respectively. Hydrolysis reaction time was fixed at 2 h. After the hydrolysis, the slurries were adjusted at $\mathrm{pH}$ 4.0 with $2 \mathrm{~mol} / \mathrm{L} \mathrm{HCl}$ and were kept in a water bath at $95^{\circ} \mathrm{C}$ for $10 \mathrm{~min}$ to inactivate the enzyme, after that, they were centrifuged $\left(10,000 \times \mathrm{g}, 30 \mathrm{~min}, 25^{\circ} \mathrm{C}\right)$; the supernatant containing the hydrolysates was recovered and preserved at $-20^{\circ} \mathrm{C}$.

\subsubsection{Angiotensin Converting Enzyme-Inhibitory (ACE-I) Activity}

To determinate the antihypertensive potential of BCBF $108 \mathrm{~h}$ was determined by its Angiotensin Converting Enzyme-Inhibitory (ACE-I) activity according to Miguel et al. [35] with modifications. ACE hydrolyses hippuryl-histidyl-leucine (HHL) to generate hippuric acid and the peptide His-Leu. The reaction mixture, consisting of the substrate (HHL) and hydrolysate sample (BCBF) was prepared in ACE buffer $(50 \mathrm{~mol} / \mathrm{L}$ sodium borate, containing $0.5 \mathrm{~mol} / \mathrm{L}$ sodium chloride, $\mathrm{pH} 8.3$ ) and was pre-incubated at $37^{\circ} \mathrm{C}$ for $5 \mathrm{~min}$, after that, ACE was added to a final concentration of $2.5 \mathrm{mU} / \mathrm{mL}$. Different dilutions of each BCBF $108 \mathrm{~h}$ hydrolysates were added and incubated in the before mentioned reaction mixture for $30 \mathrm{~min}$ at $37^{\circ} \mathrm{C}$; after that, the reactions were stopped by addition of $150 \mu \mathrm{L}$ of $1 \mathrm{~mol} / \mathrm{L} \mathrm{HCl}$ solution, followed by addition of $1 \mathrm{~mL}$ of ethyl acetate, to extract hippuric acid, and mixed by vortex for $1 \mathrm{~min}$. The mixture was centrifugated at $14,000 \times \mathrm{g}$ at $25^{\circ} \mathrm{C}$ for $10 \mathrm{~min}, 750 \mu \mathrm{L}$ of the organic phase was collected and transferred into a test tube and evaporated. The residue was dissolved in 600 $\mu \mathrm{L}$ water and concentration of hippuric acid was determined at $228 \mathrm{~nm}$ using water as a blank. In order to determinate the $\mathrm{IC}_{50}$ of sample, data were adjusted to a non-linear regression model using Hill's equation [36].

\subsection{Chemical Composition}

The following AOAC methods [37] were used to determine chemical composition: drying at $130^{\circ} \mathrm{C}$ for moisture (method 925.09B), and micro-Kjeldahl for protein $(N \times$ 6.25) (method 960.52). Soluble and insoluble fiber (method 985.29) were carried out with a commercial total dietary fiber assay kit from Sigma-Aldrich, meanwhile, resistant starch content were determined using resistant starch assay kit from Megazyme. The enzymatic assay was conducted according to a laboratory protocol based on AACC [38] method 32 - 40.

\subsection{Physicochemical Properties}

\subsubsection{Total Color Difference ( $\Delta E)$}

The surface color of the samples was measured using a Minolta color difference meter Model CR-210 (Minolta LTD, Osaka, Japan). The parameters $L(0=$ black, $100=$ white $), a(+$ value $=$ red, - value $=$ green $)$ and $b(+$ value 
$=$ yellow, - value $=$ blue) were recorded. The $L, a$ and $b$ values of a white standard tile used as reference were $97.63,-0.78$ and 2.85 , respectively. $\Delta E$ was calculated as $\Delta E=\left[(\Delta L)^{2}+(\Delta a)^{2}+(\Delta b)^{2}\right]^{1 / 2}$, where $\Delta L=\mathrm{L}_{\text {std }}-\mathrm{L}_{\text {sample }}$, $\Delta a=\mathrm{a}_{\text {std }}-\mathrm{a}_{\text {sample }}$ and $\Delta b=\mathrm{b}_{\text {std }}-\mathrm{b}_{\text {sample }}$.

\subsubsection{Water Activity $\left(A_{w}\right)$}

This parameter was determined in $5 \mathrm{~g}$ flour samples, tempered at $25^{\circ} \mathrm{C}$, using a Hygrometer Aqua Lab Model CX-2 (Decagon Devices Inc., Pullman, WA, USA), which was calibrated with a saturated potassium chloride solution $\left(\mathrm{A}_{\mathrm{w}}=0.841\right.$ at $\left.25^{\circ} \mathrm{C}\right)$. Readings were taken after leaving the sample for $1 \mathrm{~h}$ to attain headspace equilibrium.

\subsection{3. $\mathrm{pH}$}

The $\mathrm{pH}$ of flour samples was recorded using a $\mathrm{pH}$ meter. Each flour sample $(10 \mathrm{~g})$ was suspended in $100 \mathrm{~mL}$ of boiling distilled water. After cooling, the slurry was shaken $\left(1500 \mathrm{rpm}, 25^{\circ} \mathrm{C}, 20 \mathrm{~min}\right)$ using an orbital shaker (Cole Parmer Model 21704-10, Cole Parmer International, Vernon Hills, IL, USA).

\subsubsection{Water Absorption Index (WAI) and Water Solubility Index (WSI)}

WAI and WSI were assessed as described by Anderson et al. [39]. Each flour sample (2.5 g) was mixed with 30 $\mathrm{mL}$ of distilled water in a tared $50 \mathrm{~mL}$ centrifuge tube. The slurry was stirred with a glass rod for $1 \mathrm{~min}$ at room temperature and centrifuged at $3000 \times \mathrm{g}$ for $10 \mathrm{~min}$. The supernatant was then poured carefully into a tared evaporating dish. The WAI was calculated from the weight of the remaining gel and expressed in gram of gel/gram of dry flour. The WSI (gram of solids/100 grams of original solids) was calculated from the weight of dry solids recovered by evaporating the supernatant overnight at $110^{\circ} \mathrm{C}$.

\subsubsection{Dispersability}

It was determinated according to Mora-Escobedo et al. [40]. Three grams of flour sample was weighed into 50 $\mathrm{mL}$ graduated conic tube; distilled water was added to each volume of $30 \mathrm{~mL}$. The sample was vigorously stirred (Ultra Turrax homogenizer, 10,000 rpm, $5 \mathrm{~min}$ ) and allowed to settle for $30 \mathrm{~min}$. The volume of settled particles was recorded and subtracted from 30 . This value was divided between 30 and multiplied by 100 to give the percentage dispersability.

\subsection{Statistical Analysis}

Analyses were performed in triplicate. The results were analyzed using one-way analysis of variance followed by Duncan's multiple range test comparisons among means with significance level of $5 \%$. Regression models and parameter estimation was performed by multiple regressions with a significance level of 5\%. Pearson correlation coefficient was used to determine correlations among means with a significance level of 5\%.

\section{Results and Discussion}

\subsection{Effect of Fermentation Time on Total Phenolic Content (TPC)}

Unprocessed common bean flour had 35.91, 156.46 and $192.37 \mathrm{mg}$ gallic acid equivalents (GAE)/100 g sample, $\mathrm{dw}$, of free, bound and total phenolic contents, respecttively (Table 1). The solid state bioconversion (SSB) increased $(p<0.05)$ free and total phenolic contents of common beans at all incubation times; bound phenolic content increased $(p<0.05)$ significantly after $60 \mathrm{~h}$ of fermentation time. The best time for producing bioprocessed common bean (added with seed coats) flour with the highest free (190.46 mg GAE/100 g sample, dw), bound (240.86 mg GAE/100 g sample, $\mathrm{dw}$ ) and total phenolic (431.33 mg GAE/100 g sample, dw) contents was $108 \mathrm{~h}$. After $108 \mathrm{~h}$ of incubation the bioprocessed cotyledons showed off odor. The SSB process by $108 \mathrm{~h}$ substantially increased $(\mathrm{p}<0.05) 2.24$ times the TPC. The increase of TPC in bioprocessed common bean (added with seed coats) flour after $108 \mathrm{~h}$ of fermentation time, observed in the present study, is consistent with findings reported by other investigators [20,41-43]. These researchers suggest that $\beta$-glucosidase, produced by fungi, catalyse the release of aglycones from the bean substrate and there by increases their TPC. Chaiyasut $e t$ $a l$. [23] studied the effect of fermentation time on isoflavone content and antioxidant activity of fermented soybeans and observed that the isoflavone content and profile of fermented soybeans are related to the duration of fermentation: isoflavone aglycones and isoflavone glycones increased and decreased, respectively, with fermentation duration. Nevertheless, it is important to consider that several factors might affect the $T P C$, such as variety, cultivation characteristics, chemical composition, particle size, sample concentration and the method of analysis [44].

\subsection{Effect of Fermentation Time on Antioxidant Activity (AoxA)}

Antioxidant activities of unprocessed and bioprocessed common bean (added with seed coats) flours were evaluated by the oxigen radical absorbance capacity (ORAC) and ABTS radical cation decolorization methods. In general, AoxA of bioprocessed bean (added with seed coats) increased with fermentation duration (Table 2). The AoxA, evaluated by ORAC assay, for free, bound and 
Table 1. Effect of fermentation time on total phenolics content in common beans.

\begin{tabular}{cccc}
\hline $\begin{array}{c}\text { Fermentation time } \\
\text { (h) }\end{array}$ & \multicolumn{3}{c}{ Phenolic compounds ${ }^{\mathrm{a}}(\mathbf{m g}$ GAE $/ \mathbf{1 0 0}$ g sample, dw) } \\
\cline { 2 - 4 } Unprocessed & Free & Bound & Total \\
Bioprocessed & $35.91 \pm 0.24^{\mathrm{G}}$ & $156.46 \pm 5.47^{\mathrm{D}, \mathrm{E}}$ & $192.37 \pm 5.68^{\mathrm{H}}$ \\
24 & & & $240.20 \pm 2.29^{\mathrm{G}}$ \\
36 & $91.32 \pm 2.59^{\mathrm{F}}$ & $148.88 \pm 4.36^{\mathrm{E}}$ & $243.63 \pm 10.75^{\mathrm{G}}$ \\
48 & $91.86 \pm 5.45^{\mathrm{F}}$ & $151.77 \pm 8.64^{\mathrm{D}, \mathrm{E}}$ & $276.18 \pm 2.90^{\mathrm{F}}$ \\
60 & $114.04 \pm 1.29^{\mathrm{E}}$ & $162.14 \pm 3.82^{\mathrm{C}, \mathrm{D}}$ & $297.27 \pm 5.23^{\mathrm{E}}$ \\
72 & $129.49 . \pm 3.96^{\mathrm{D}}$ & $167.78 \pm 8.28^{\mathrm{C}}$ & $317.83 \pm 1.42^{\mathrm{D}}$ \\
84 & $134.03 \pm 0.84^{\mathrm{D}}$ & $183.79 \pm 1.77^{\mathrm{B}}$ & $344.46 \pm 9.77^{\mathrm{C}}$ \\
96 & $150.81 \pm 6.25^{\mathrm{C}}$ & $193.66 \pm 3.57^{\mathrm{B}}$ & $362.54 \pm 8.15^{\mathrm{B}}$ \\
\hline
\end{tabular}

${ }^{\mathrm{a}}$ Data were expressed as means \pm standard deviations; mg GAE: Miligrams of gallic acid equivalents; ${ }^{\mathrm{A}-\mathrm{H}}$ Means with different superscripts in the same column are significantly different.

Table 2. Effect of fermentation time on antioxidant activity of common beans evaluated by $O R A C$ and $A B T S$ assays.

\begin{tabular}{|c|c|c|c|c|c|c|}
\hline \multirow{3}{*}{$\begin{array}{l}\text { Fermentation time } \\
\text { (h) }\end{array}$} & \multicolumn{6}{|c|}{ Antioxidant activity $(\mu \mathrm{mol} \mathrm{TE} / 100 \mathrm{~g}$ sample, $\mathrm{dw})$} \\
\hline & \multicolumn{3}{|c|}{ ORAC } & \multicolumn{3}{|c|}{ ABTS } \\
\hline & Free & Bound & Total & Free & Bound & Total \\
\hline Unprocessed & $2018 \pm 90^{\mathrm{F}}$ & $4383 \pm 120^{\mathrm{E}}$ & $6402 \pm 130^{\mathrm{F}}$ & $517 \pm 23^{\mathrm{G}}$ & $4992 \pm 225^{\mathrm{C}}$ & $5509 \pm 595^{\mathrm{F}}$ \\
\hline \multicolumn{7}{|l|}{ Bioprocessed } \\
\hline 24 & $5827 \pm 140^{\mathrm{E}}$ & $5402 \pm 134^{\mathrm{D}}$ & $11,230 \pm 140^{\mathrm{E}}$ & $933 \pm 60^{\mathrm{G}}$ & $3747 \pm 317^{\mathrm{D}}$ & $4679 \pm 140^{\mathrm{G}}$ \\
\hline 36 & $5618 \pm 56^{\mathrm{E}}$ & $6543 \pm 229^{\mathrm{C}}$ & $12,162 \pm 223^{\mathrm{D}}$ & $1432 \pm 376^{\mathrm{F}}$ & $4149 \pm 298^{\mathrm{D}}$ & $5582 \pm 223^{\mathrm{F}}$ \\
\hline 48 & $6582 \pm 340^{\mathrm{D}}$ & $7280 \pm 332^{\mathrm{A}, \mathrm{B}}$ & $13,862 \pm 219^{\mathrm{C}}$ & $2984 \pm 294^{\mathrm{E}}$ & $4916 \pm 281^{\mathrm{C}}$ & $7900 \pm 319^{\mathrm{E}}$ \\
\hline 60 & $6802 \pm 242^{\mathrm{C}, \mathrm{D}}$ & $7549 \pm 255^{\mathrm{A}}$ & $13,863 \pm 169^{\mathrm{C}}$ & $3480 \pm 153^{\mathrm{D}}$ & $4994 \pm 297^{\mathrm{C}}$ & $8475 \pm 269^{\mathrm{D}}$ \\
\hline 72 & $7042 \pm 549^{\mathrm{C}, \mathrm{D}}$ & $6759 \pm 195^{\mathrm{C}}$ & $13,802 \pm 362^{\mathrm{C}}$ & $3890 \pm 313^{\mathrm{D}}$ & $4854 \pm 202^{\mathrm{C}}$ & $8745 \pm 262^{\mathrm{D}}$ \\
\hline 84 & $7350 \pm 570^{\mathrm{C}}$ & $6666 \pm 390^{\mathrm{C}}$ & $14,217 \pm 231^{\mathrm{C}}$ & $4673 \pm 355^{\mathrm{C}}$ & $5762 \pm 220^{\mathrm{B}}$ & $10,435 \pm 331^{\mathrm{C}}$ \\
\hline 96 & $8454 \pm 157^{\mathrm{B}}$ & $6948 \pm 333^{\mathrm{B}, \mathrm{C}}$ & $15,402 \pm 280^{\mathrm{B}}$ & $5267 \pm 404^{\mathrm{B}}$ & $6093 \pm 269^{\mathrm{B}}$ & $11,360 \pm 280^{\mathrm{B}}$ \\
\hline 108 & $10,160 \pm 212^{\mathrm{A}}$ & $7308 \pm 117^{\mathrm{A}, \mathrm{B}}$ & $17,468 \pm 206^{\mathrm{A}}$ & $6207 \pm 285^{\mathrm{A}}$ & $7298 \pm 288^{A}$ & $13,505 \pm 206^{\mathrm{A}}$ \\
\hline
\end{tabular}

${ }^{\mathrm{a}}$ Data were expressed as means \pm standard deviations; $\mu \mathrm{mol}$ TE: Micromols of trolox equivalents; ${ }^{\mathrm{A}-\mathrm{G}}$ Means with different superscripts in the same column are significantly different.

total phytochemicals ranged from 2018 to 10,160 , from 4383 to 7308 and from 6402 to $17,468 \mu \mathrm{mol}$ trolox equivalents (TE)/100 g sample, $\mathrm{dw}$, respectively. ORAC values for total phytochemicals from bioprocessed common beans (added with seed coats) were different $(\mathrm{p}<$ 0.05 ) at $0,24,36,48,84,96$, and $108 \mathrm{~h}$ of incubation time. The highest total hydrophilic antioxidant activity of bioprocessed common bean (added with seed coats) was achieved at fermentation time of $108 \mathrm{~h}($ ORAC value $=$ $17,468 \mu \mathrm{mol} \mathrm{TE} / 100 \mathrm{~g}$ sample, dw). After $108 \mathrm{~h}$ of in- cubation time the bioprocessed common bean cotyledons showed off odor. The AoxA, evaluated by ABTS method, for free, bound and total phytochemicals varied from 517 to 6207 , from 4992 to 7298 and from 5509 to 13,505 $\mu \mathrm{mol} \mathrm{TE} / 100 \mathrm{~g}$ sample, $\mathrm{dw}$, respectively (Table 2). $A B T S$ values for total phytochemicals from bioprocessed common beans (added with seed coats) at $60-72 \mathrm{~h}$ of fermentation duration are not significantly $(\mathrm{p}>0.05)$ different. The highest AoxA of bioprocessed common beans (added with seed coats) can be achieved after be- 
ing fermented for $108 \mathrm{~h}$. Both $O R A C$ and $A B T S$ methods showed similar tendency. The study also revealed that the total phenolics content and antioxidant activity of bioprocessed common beans (added with seed coats) correlated (regression analysis) with fermentation duration $(\mathrm{p}=0.000)$. The high regression coefficients of determination $\left(\mathrm{R}^{2}=0.876-0.978\right)$ indicated a good correlation coefficient $(r=0.936-0.989)$ between experimental and predicted data. The regression models for total phenolic content and antioxidant activity were: TPC $=227.9+0.1248 \mathrm{t}+0.01527 \mathrm{t}^{2}\left(\mathrm{R}^{2}=0.978, \mathrm{R}_{\text {adj }}^{2}=0.969\right)$; AoxA $($ ORAC $)=10015+60.4 \mathrm{t}\left(\mathrm{R}^{2}=0.876, \mathrm{R}_{\text {adj }}^{2}=\right.$ $0.856) ; \operatorname{AoxA}(A B T S)=2383+97.8 \mathrm{t}\left(\mathrm{R}^{2}=0.970, \mathrm{R}^{2}{ }_{\text {adj }}=\right.$ 0.965); where: $\mathrm{t}=$ fermentation time. The regression models of TPC and AoxA showed high significance ( $\mathrm{p}=$ $0.000)$, non-significant lack of fit ( $p>0.05$ ), and the relative dispersion of the experimental points from the predictions of the models $(\mathrm{CV})$ was $<10 \%$. Based on this analysis, the selected model represented adequately the datas of $T P C$ and both $O R A C$ and ABTS methods for AoxA.The results indicate that bioprocessed common beans (added with seed coats) showed the highest TPC and the total hydrophilic AoxA at $108 \mathrm{~h}$ of fermentation time. These results are in agreement with those reported by other researchers $[20,21]$ who found that solid state bioconversion (SSB) would increase the TPC and AoxA of fungal processed seed and legumes which will enhance the potential health-relevant functionality. $S S B$ is a good strategy to improve the TPC of common beans for enhanced functionality with improved AoxA. Therefore, $S S B$ of common beans at $108 \mathrm{~h}$ was selected for producing multipurpose bioprocessed common bean (added with seed coats) flour with high antioxidant capacity and nutraceutical potential; its proximate composition and physicochemical properties are shown in Table 3.

\subsection{Correlation between Phenolic Content and Antioxidant Activity}

A highly significant correlation was found between $T P C$ and total hydrophilic antioxidant activity (ORAC value) in bioprocessed common beans (added with seed coats) flours (Pearson's correlation coefficient $r=0.905 ; \mathrm{p}=$ 0.000 ). The positive linear correlation obtained is considered extremely significant due to the high coefficient of determination $\left(r^{2}=0.8186\right)$. A similar effect was observed between TPC and antioxidant activity assayed by $A B T S$ method (Pearson's correlation coefficient $\mathrm{r}=0.962$; $\mathrm{p}=0.000)$. The positive linear correlation obtained is considered extremely significant due to the high coefficient of determination $\left(r^{2}=0.9263\right)$. Other researchers $[19,45-48]$ have reported, in whole raw legume seeds, a highly significant correlation between TPC and AoxA.
Table 3. Nutritional, physicochemical and antioxidant properties $^{\mathrm{a}}$ of unprocessed (raw) and bioprocessed common bean flours.

\begin{tabular}{|c|c|c|}
\hline \multirow[t]{2}{*}{ Property } & \multicolumn{2}{|c|}{ Common bean flour } \\
\hline & Unprocessed & Bioprocessed \\
\hline \multicolumn{3}{|l|}{$\begin{array}{c}\text { Chemical composition } \\
(\%, d w)\end{array}$} \\
\hline Crude protein & $25.36 \pm 0.59^{\mathrm{B}}$ & $29.54 \pm 2.13^{\mathrm{A}}$ \\
\hline Total dietary fiber & $28.02 \pm 1.00^{\mathrm{B}}$ & $39.17 \pm 0.97^{\mathrm{A}}$ \\
\hline Soluble & $4.74 \pm 0.05^{\mathrm{B}}$ & $13.32 \pm 1.03^{\mathrm{A}}$ \\
\hline Insoluble & $11.30 \pm 0.02^{\mathrm{B}}$ & $22.51 \pm 0.14^{\mathrm{A}}$ \\
\hline Resistant starch & $2.41 \pm 0.27^{\mathrm{B}}$ & $5.55 \pm 0.17^{\mathrm{A}}$ \\
\hline \multicolumn{3}{|l|}{ Physicochemical } \\
\hline \multicolumn{3}{|l|}{ Color } \\
\hline Hunter "L" value & $88.34 \pm 0.25^{\mathrm{A}}$ & $64.01 \pm 0.41^{\mathrm{B}}$ \\
\hline Total color difference & $12.04 \pm 0.48^{\mathrm{B}}$ & $24.90 \pm 0.71^{\mathrm{A}}$ \\
\hline $\mathrm{pH}$ & $6.00 \pm 0.16^{\mathrm{A}}$ & $5.7 \pm 0.27^{\mathrm{B}}$ \\
\hline Water activity & $0.51 \pm 0.01^{\mathrm{A}}$ & $0.50 \pm 0.01^{\mathrm{A}}$ \\
\hline $\begin{array}{l}\text { Water absorption index } \\
\text { (g gel/g dry flour) }\end{array}$ & $2.33 \pm 0.07^{\mathrm{B}}$ & $3.10 \pm 0.04^{\mathrm{A}}$ \\
\hline $\begin{array}{l}\text { Water solubility index ( } \mathrm{g} \\
\text { soluble solids/100 g total } \\
\text { solids, } \mathrm{dw} \text { ) }\end{array}$ & $17.39 \pm 2.13^{\mathrm{B}}$ & $21.22 \pm 0.25^{\mathrm{A}}$ \\
\hline Dispersability (\%) & $30 \pm 0.00^{\mathrm{B}}$ & $100 \pm 0.00^{\mathrm{A}}$ \\
\hline \multicolumn{3}{|l|}{ Antioxidant activity } \\
\hline $\begin{array}{l}\text { Total ORAC ( } \mu \mathrm{mol} \\
\text { TE/100 g sample, dw) }\end{array}$ & $6402 \pm 19^{\mathrm{B}}$ & $17,468 \pm 206^{\mathrm{A}}$ \\
\hline $\begin{array}{c}\text { Total ABTS }(\mu \mathrm{mol} \\
\text { TE/100 g sample, dw })\end{array}$ & $5509 \pm 301^{\mathrm{B}}$ & $13,505 \pm 536^{\mathrm{A}}$ \\
\hline \multicolumn{3}{|l|}{ Antihypertensive activity } \\
\hline $\mathrm{IC}_{50}(\mu \mathrm{g} / \mathrm{mL})$ & $79.22 \pm 0.0377^{\mathrm{A}}$ & $0.0117 \pm 0.007^{\mathrm{B}}$ \\
\hline
\end{tabular}

${ }^{a}$ Data were expressed as means \pm standard deviations; $\mu \mathrm{mol}$ TE: Micromols of trolox equivalents; ${ }^{\mathrm{A}, \mathrm{B}}$ Means with different superscripts in the same raw are significantly different.

Phenolic compounds are considered the major compounds that contribute to the total antioxidant activities of the grains [47]. These compounds have been associated with a reduction in the risk of cancer, heart disease, and diabetes, as well as to have antibacterial, antiviral, anti-inflammatory, and anti-allergenic activities; most of these benefits result from their antioxidant activity [49].

\subsection{Angiotensin Converting Enzyme-Inhibitory (ACE-I) Activity}

To determinate the potential antihypertensive activity in 
a compound, $\mathrm{IC}_{50}$ value must be calculated. $\mathrm{IC}_{50}$ value is defined as the concentration needed to inhibit $50 \%$ the activity of Angiotensin Converting Enzyme (ACE), while this value is smaller, means that the inhibitor has a greater potential antihypertensive. Unprocessed and BCBF [bioprocessed $(108 \mathrm{~h})$ common bean flour] were digested with pancreatin enzyme, that is a mixture of several digestive enzymes, its hydrolysates could provide information of the nutraceutical benefits of BCBF $108 \mathrm{~h}$ consumption. The BCBF had lower $(\mathrm{p}<0.05) \mathrm{IC}_{50}$ than unprocessed legume $(0.0117 \mathrm{vs} 79.22 \mu \mathrm{g} / \mathrm{mL})$ (Table 3). During common bean bioprocessing by SSB exists release of bioactive substances such as phytochemicals [in the presente study an increase in free, bound and total phenolic contents in bioprocessed common bean (added with seed coats) flour was observed after $108 \mathrm{~h}$ of fermentation time (Table 1)] or partial hydrolysis of peptides, and in addition the gastrointestinal digestion may have release of peptides, and many other bioactive compounds capable of inhibiting ACE. The Figure 1 shows the non-linear fit plots of unproccesed and bioproccesed common beans hydrolysates ACE-I evaluations; it can be observed that hydrolysates from BCBF shows the nonlinear fit plots of unproccesed and bioproccesed common beans hydrolysates ACE-I evaluations; it can be observed that hydrolysates from BCBF showed the highest ACE inhibitory activity percentage $(93 \%)$. Some researchers $[11,13,50]$ have reported that common bean seeds are a valuable source of ACE inhibitors (ACE increases blood pressure by converting the inactive decapeptide angiotensin I to the potent vasoconstrictor angiotensin II

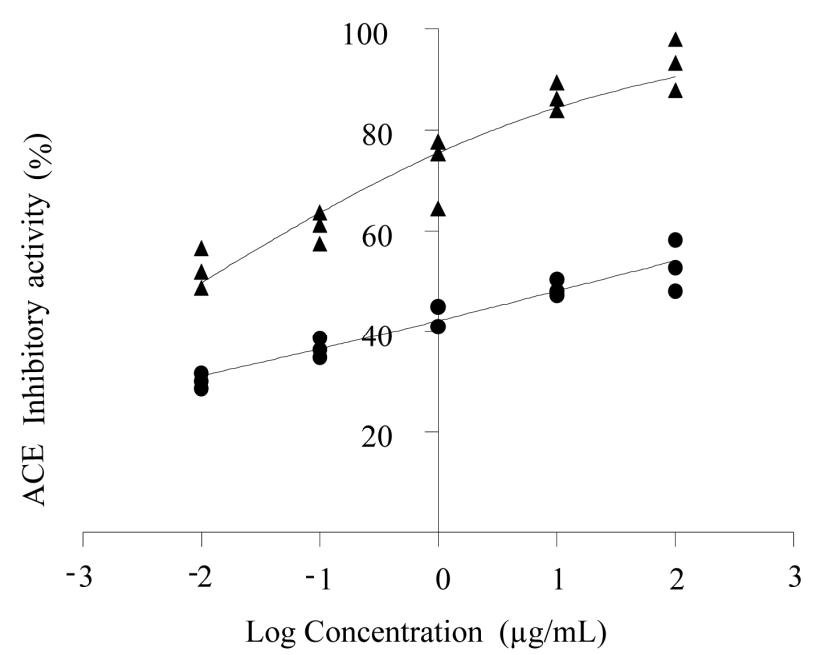

Figure 1. Comparision of ACE inhibitory activity of unprocessed $(\bullet)$ and bioprocessed $(\Delta)$ common bean hydrolysates treated by pancreatin. Continuous lines represent the non linear regression using Hill's equation for each data set. Values are means for three measurements per hydrolysate. and inactivating the vasodilator bradykinin [35]). Therefore, inhibition of ACE reduces the activity of angiotensin II but increases bradykinin levels, and thus can result in a lowering of blood pressure. It has been reported that many natural ACE inhibitors isolated from the hydrolysis of various grains proteins such soybean [12], wheat germ [51], amaranth [52], common beans [13] or during gastrointestinal digestion or foodprocessing $[14,15]$ can be used as pharmaceuticals and physiological functional food supplements for hypertension therapy. Valdez-Ortiz et al. [11] reported, for protein concentrates of three cultivars of azufrado beans hydrolyzed with pancreatic enzyme, $\mathrm{IC}_{50}=60-319 \mu \mathrm{g} / \mathrm{mL}$. The results obtained in this work are encouraging, because $\mathrm{IC}_{50}$ values were lower than those reported for fermented products of soybean $(80-360 \mu \mathrm{g} / \mathrm{mL})$ [15] and lentils (180 $200 \mu \mathrm{g} / \mathrm{mL}$ ) [53], and pepsin-pancreatin hydrolysates from lima bean $(250-692 \mu \mathrm{g} / \mathrm{mL})$ [54].

\subsection{Chemical Composition and Physicochemical and Nutraceutical Properties of Bioprocessed (108 h) Common Bean (Added with Seed Coats) Functional Flour}

Solid state bioconversion (SSB) of common beans with Rhizopus oligosporus at $35^{\circ} \mathrm{C}$ and $108 \mathrm{~h}$ of fermentation increased $(\mathrm{p}<0.05)$ crude protein content $(\mathrm{dw})$ from $25.36 \%$ to $29.54 \%$ (Table 3). Paredes-López et al. [55] reported that during the initial steps (soaking, cooking) of SSB processing of chickpea for animal consumption the total protein content increased significantly $(9.4 \%)$, which might be due to leaching of solid material during these treatments; furthermore, they found that fermentation for $72 \mathrm{~h}$ increased the protein content significantly $(21.7 \%)$, which may reflect an increase in mould biomass [56].

The soluble, insoluble and total dietary fiber, and resistant starch contents in common beans increased $(\mathrm{p}<$ 0.05 ), in dry weight, from $4.74 \%$ to $13.32 \%$, from $11.30 \%$ to $22.51 \%$, from $28.02 \%$ to $39.17 \%$, and from $2.41 \%$ to $5.55 \%$, respectively, after bioprocessing $(108 \mathrm{~h})$ (Table 3). The presence of dietary fiber and resistant starch in foods is important in health because they have been considered as functional ingredients to reduce colon cancer and battle $[10,57]$. These changes may be due to leaching out some compounds during steeping and cooking steps (before fermentation) and to fungi grow which have consumed carbohydrates and fat as an energy sources and the development of a fiber-rich fungous mycelium [58]. Gelatinisation and retrogradation of the starch are important processes that govern the formation of resistant starch; during SSB process the content of moisture and cooking temperature, the action of water on the hydrogen bonds between molecular chains within the 
starch granular are former. Resistant starch is a fraction of starch that is not digested by amylolytic enzymes in the digestive track but is fermented by the gut bacteria in the colon and produces short-chain fatty acids and others organic acids. They are interest in consuming RS because of its health benefits including reduction of the glycemic and insulinemic responds to foods, obesity, diabetis, cardiovascular disease and colon cancer $[59,60]$.

Bioprocessed common beans (added with seed coats) flour had lower $(\mathrm{p}<0.05)$ Hunter " $L$ " value and $\mathrm{pH}$, higher $(\mathrm{p}<0.05) \Delta E$, and similar $(\mathrm{p}>0.05)$ water activeity than unprocessed whole common bean flour (Table 3). Soaking and cooking produced a significant increase in the " $L$ " value of common beans, meaning a lighter color (data not shown), but fermentation resulted in a slightly darker color, probably due to the influence of mycelia color and the drying step. Despite the bioprocessed common bean (added with seed coats) flour had a higher $\Delta E$ than the unprocessed sample, the color of bioprocessed common bean flour looked acceptable, although sensory studies were not conducted.

Bioprocessed common bean (added with seed coats) flour showed higher $(\mathrm{p}<0.05)$ water absorption $(W A I)$ and water solubility (WSI) indexes than unprocessed whole common bean flour (Table 3); partial protein denaturation and starch gelatinization occurring during the cooking step may be responsible for these changes. The dispersability was much higher in bioprocessed common bean than unprocessed common bean flour $(100 \%$ vs $39 \%$ ). Angulo-Bejarano et al. [61] reported, for bioprocessed (with Rhizopus oligosporus at $34.9^{\circ} \mathrm{C}$ and $51.2 \mathrm{~h}$ ) chickpeas (without added seed coats) WAI, WSI and dispersability values of $4.2 \mathrm{~g}$ gel $/ \mathrm{g}$ sample $(\mathrm{dw}), 11.3 \mathrm{~g}$ soluble solids $/ 100 \mathrm{~g}$ original solids, and $66.5 \%$, respectively.

The bioprocessed $(108 \mathrm{~h})$ common bean functional flour $(100 \mathrm{~g})$ shows a total antioxidant activity of 17,468 $\mu \mathrm{mol}$ TE and 13,505 $\mu \mathrm{mol} \mathrm{TE}$, evaluated by ORAC and ABTS methodologies, respectively. The USDA recommends a daily intake of 3000 to $5000 \mu \mathrm{mol}$ TE (ORAC value) to maintain an adequate level of antioxidants in the body [62]. A $20 \mathrm{~g}$ portion of the bioprocessed common bean functional flour contributes with $54 \%-116 \%$ of the recommended daily intake for antioxidants.

\section{Conclusion}

Solid state bioconversion can be an efficient strategy to improve the phenolic content and antioxidant activity of these common bean extracts with associated healthlinked functionality enhancement. At fermentation time of $108 \mathrm{~h}$ there is enhancement of total phenolics and antioxidant activity in the bioprocessed common beans (added with seed coats) extracts. Bioprocessed common beans (added with seed coats) extracts are potentially safer, so therefore may be a preferred alternative for a nutraceutical ingredient/supplement development for prevention and control of degenerative diseases such as hypertension and those derived from oxidative stress.

\section{Acknowledgements}

This research was supported by grants Programa de Fomento y Apoyo a Proyectos de Investigación (PROFAPI 2011, 2012), Universidad Autónoma de Sinaloa and Fundación Produce Sinaloa, AC $(2010,2011,2012)$.

\section{REFERENCES}

[1] K. Sowndharajan, P. Siddhuraju and S. Manian, "In Vitro Evaluation of the Antioxidant Activities in the Differentially Processed Seeds from Underutilized Legume, Bauhinia Vahilii Wight and Arn," Food Science and Biotechnology, Vol. 19, No. 2, 2010, pp. 503-509.

doi:10.1007/s10068-010-0070-6

[2] W. Wiczkowski and M. K. Piskula, "Food Flavonoids," Polish Journal of Food Nutrition Science, Vol. 13, 2004, pp. 101-114.

[3] V. Cheynier, "Polyphenols in Foods Are More Complex than Often Thought," American Journal of Clinical Nutrition, Vol. 81, No. 1, 2005, pp. 223-229.

[4] R. Pilarski, H. Zielinski, D. Ciesiolka and K. Gulewicz, "Antioxidant Activity of Ethanolic and Aqueous Extracts of Uncaria tomentosa (Willd.) DC," Journal of Ethnopharmacology, Vol. 104, No. 1-2, 2006, pp. 18-23. doi:10.1016/j.jep.2005.08.046

[5] A. Romani, P. Vignolini, C. Galardi, N. Mulinacci, S. Benedettelli and D. HeimLer, "Germplasm Characterization by Zolfino Landraces (Phaseolus vulgaris L.) by Flavonoid Content," Journal of Agricultural and Food Chemistry, Vol. 52, No. 12, 2004, pp. 3838-3842. doi:10.1021/jf0307402

[6] T. Madhujith and F. Shahidi, "Antioxidant Potential of Pea Beans (Phaseolus vulgaris L.)", Journal of Food Science, Vol. 70, No. 1, 2005, pp. 85-90. doi:10.1111/j.1365-2621.2005.tb09071.x

[7] B. D. Oomah, A. Cardador-Martinez and G. Loarca-Piña, "Phenolics and Antioxidative Activities in Common Beans (Phaseolus vulgaris L)," Journal of the Science and Food Agriculture, Vol. 85, No. 6, 2005, pp. 935-942. doi:10.1002/jsfa.2019

[8] L. Bazzano, J. He, L.G. Ogden, C. Loria, S. Vupputuri, L. Myers and P. K. Whelton, "Legume Consumption and Risk of Coronary Heart Disease in US Men and Women," Archives of Internal Medicine, Vol. 161, No. 21, 2001, pp. 2573-2578. doi:10.1001/archinte.161.21.2573

[9] X. Aparicio-Fernández, T. García-Gasca, G. G. Yousef, M. A. Lila, E. G. de Mejía and G. Loarca-Piña, "Chemopreventive Activity of Polyphenolics from Black Jamada Bean (Phaseolus vulgaris L.) on HeLa and HaCaT Cells," Journal of Agricultural and Food Chemistry, Vol. 54, No. 


\section{6, 2006, pp. 2116-2122. doi:10.1021/jf052974m}

[10] R. Reynoso-Camacho, M. C. Ríos-Ugalde, I. Torres-Pacheco, J. A. Acosta-Gallegos, A. C. Palomino-Salinas, M. Ramos-Gómez, E. González-Jasso and S. H. GuzmánMaldonado, "El Consumo de Frijol Común (Phaseolus vulgaris L) y su Efecto Sobre el Cáncer de Colon en Ratas Sprague-Dauley," Agricultura Técnica de México, Vol. 33, 2007, pp. 43-52.

[11] A. Valdez-Ortiz, C. I. Fuentes-Gutiérrez, L. J. GermánBáez, R. Gutiérrez-Dorado and S. Medina-Godoy, "Protein Hydrolysates Obtained from Azufrado (Sulphur Yellow) Beans (Phaseolus vulgaris): Nutritional, ACE-Inhibitory and Antioxidative Characterization," Food Science and Technology, Vol. 46, 2012, pp. 91-96.

[12] A. Moure, H. Domínguez and J. C. Parajo, "Antioxidant Properties and Ultrafiltration-Recovered Soy Protein Fractions from Industrial Effluents and Their Hydrolysates," Process Biochemistry, Vol. 41, No. 2, 2006, pp. 447-452. doi:10.1016/j.procbio.2005.07.014

[13] A. J. Hernández-Álvarez, G. Dávila-Ortız, C. JiménezMartínez and C. Jacinto-Hernández, "Isolation and Characterization of Bioactive Peptides from Seed of Bean (Phaseolus vulgaris var. Jamapa)," Food Science and Food Biotechnology in Developing Countries, Vol. 19, 2008, pp. 505-509.

[14] W. Wang and E. G. de Mejia, "A New Frontier in Soy Bioactive Peptides That May Prevent Age-Related Chronic Diseases," Comprehensive Reviews in Food Science and Food Safety, Vol. 4, No. 4, 2005, pp. 63-78. doi:10.1111/j.1541-4337.2005.tb00075.x

[15] Y. H. Pyo and T. C. Lee, "The Potential Antioxidant Capacity and Angiotensin-I Converting Enzyme Inhibitory Activity of Monascus-Fermented Soybean Extracts: Evaluation of Monascus-Fermented Soybean Extracts as Multifunctional Food Additives," Journal of Food Science, Vol. 72, No. 3, 2007, pp. S218-S223. doi:10.1111/j.1750-3841.2007.00312.x

[16] U. Holker and J. Lenz, "Solid-State Fermentation-Are There Any Biotechnological Advantages?" Current Opinion in Microbiology, Vol. 8, No. 3, 2005, pp. 301-306. doi:10.1016/j.mib.2005.04.006

[17] A. Sharma and N. Khetarpaul, "Effect of Fermentation on Phytic Acid Content and in Vitro Digestibility of Starch and Protein of Rice-Black Gram Dhal-Wheat Blends," Journal of Food Science and Technology, Vol. 34, 1997, pp. 20-30.

[18] E. Berghofer, B. Grzeskowiak, N. Mundigler, W. B. Sentall and J. Walcak, "Antioxidative Properties of Faba Bean, Soybean and Oat Tempeh," International Journal of Food Science and Nutrition, Vol. 49, No. 1, 1998, pp. 45-54. doi:10.3109/09637489809086403

[19] H. Han and B. K. Baik, "Antioxidant Activity and Phenolic Content of Lentils (Lens culinaris), Chickpeas (Cicer arietinum L.), Peas (Pisum sativum L.) and Soybeans (Glycine max), and Their Quantitative Changes during Processing," International Journal of Food Science and Technology, Vol. 43, 2008, pp. 1971-1978. doi:10.1111/j.1365-2621.2008.01800.x
[20] M. Reyes-Bastidas, E. Z. Reyes-Fernández, J. López-Cervantes, J. Milán-Carrillo, G. F. Loarca-Pila and C. ReyesMoreno, "Physicochemical, Nutritional and Antioxidant Activity Properties of Tempeh from Common Beans (Phaseolus vulgaris L)," Food Science and Technology International, Vol. 16, No. 5, 2010, pp. 427-434. doi:10.1177/1082013210367559

[21] D. Maiti and M. Majumdar, "Impact of Bioprocessing on Phenolic Content and Antioxidant Activity of Two Edible Seeds to Improve Hypoglycemic Functionality," Journal of Natural Pharmaceuticals, Vol. 3, 2012, pp. 31-36

[22] C. Chen-Tien, H. Cheng-Kuang, C. Su-Tze, C. Ya-Chen, H. Feng-Sheng and C. Yun-Chin, "Effect of Fermentation Time on the Antioxidant Activities of Tempeh Prepared from Fermented Soybean Using Rhizopus oligosporus," International Journal of Food Science and Technology, Vol. 44, No. 4, 2009, pp. 799-806. doi:10.1111/j.1365-2621.2009.01907.x

[23] C. Chaivasut, T. Kumar, P. Tipduangta and W. Rungseevijitprapa, "Isoflavone Content and Antioxidant Activity of Thai Fermented Soybean and Its Capsule Formulation," African Journal of Biotechnology, Vol. 9, 2010, pp. 4120-4126.

[24] B. P. Sousa and R. T. P. Correia, "Phenolic Content, Antioxidant Activity and Antiamylolytic Activity of Extracts Obtained from Bioprocessed Pineapple and Guava Wastes," Brazilian Journal of Chemical Engineering, Vol. 29, 2012, pp. 25-30

[25] C. Reyes-Moreno, E. O. Cuevas-Rodríguez, J. Milán-Carrillo, O. G. Cárdenas-Valenzuela and J. Barrón-Hoyos, "Solid State Fermentation Process for Producing Chickpea (Cicer arietinum L) Tempe Flour. Physicochemical and Nutritional Characteristics of the Product," Journal of the Science of Food and Agriculture, Vol. 84, No. 3, 2004, pp. 271-278. doi:10.1002/jsfa.1637

[26] V. Dewanto, X. Wu and R. H. Liu, "Processed Sweet Corn Has Higher Antioxidant Activity," Journal of Agricultural and Food Chemistry, Vol. 50, No. 17, 2002, pp. 4959-4964. doi:10.1021/jf0255937

[27] K. K. Adom and R. H. Liu, "Antioxidant Activity of Grains," Journal of Agricultural and Food Chemistry, Vol. 50, No. 21, 2002, pp. 6182-6187. doi:10.1021/jf0205099

[28] S. Mora-Rochín, J. A. Gutiérrez-Uribe, S. O. Serna-Saldivar, P. Sánchez-Peña, C. Reyes-Moreno and J. MilánCarrillo, "Phenolic Content and Antioxidant Activity of Tortillas Produced from Pigmented Maize Processed by Conventional Nixtamalization or Extrusion Cooking," Journal of Cereal Science, Vol. 52, No. 3, 2010, pp. 502508. doi:10.1016/i.jes.2010.08.010

[29] V. L. Singleton, R. Orthofer and R. M. Lamuela-Raventos, "Analysis of Total Phenols and Other Oxidation Substrates and Antioxidants by Means of Folin-Ciocalteu Reagent," Methods in Enzymology, Vol. 299, 1999, pp. 152-178. doi:10.1016/S0076-6879(99)99017-1

[30] G. Cao, H. M. Alessio and R. Culter, "Oxygen-Radical Absorbance Capacity Assays for Antioxidants," Free Radical Biology and Medicine, Vol. 14, No. 3, 1993, pp. 


\section{3-311. doi:10.1016/0891-5849(93)90027-R}

[31] B. Ou, M. Hampsch-Woodill and R. L. Prior, "Development and Validation of an Improved Oxygen Radical Absorbance Capacity Assay Using Fluorescein as the Fluorescent Probe," Journal of Agricultural and Food Chemistry, Vol. 49, No. 10, 2001, pp. 4619-4626. doi:10.1021/jf010586o

[32] R. Re, N. Pellegrini, A. Proteggente, A. Pannala, M. Yang and C. Rice-Evans, "Antioxidant Activity Applying an Improved ABTS Radical Cation Decolorization Assay," Free Radical Biology and Medicine, Vol. 26, No. 9-10, 1999, pp. 1231-1237. doi:10.1016/S0891-5849(98)00315-3

[33] L. M. Humiski and R. E. Aluko, "Physicochemical and Bitterness Properties of Enzymatic Pea Protein Hydrolysates," Journal of Food Science, Vol. 72, 2007, pp. 605611. doi:10.1111/j.1750-3841.2007.00475.x

[34] J. Adler-Nissen, "Enzymatic Hydrolysis of Food Proteins," Elsevier Applied Science Publication, New York, 1986.

[35] M. Miguel, M. A. Aleixandre, M. Ramos and R. LópezFandiño, "Effect of Simulated Gastrointestinal Digestion on the Antihypertensive Properties of ACE-Inhibitory Peptides Derived from Ovalbumin," Journal of Agricultural and Food Chemistry, Vol. 54, No. 3, 2006, pp. 726731. doi:10.1021/jf051101p

[36] H. J. Motulsky and A. Christopoulos, "Fitting Models to Biological Data Using Linear and Nonlinear Regression," A Practical Guide to Curve Fitting, GraphPad Software Inc., San Diego, 2003.

[37] AOAC, "Association of Official Analytical Chemists," 16th Edition, Official Methods of Analysis, Association of Official Analytical Chemists, Washington DC, 1999.

[38] American Association of Cereal Chemists, "Approved Methods of the American Association of Cereal Chemists," AACC, St. Paul, 2000.

[39] R. A. Anderson, H. F. Conway, V. F. Pfeifer and E. Griffin, "Gelatinization of Corn Grits by Roll and Extrusion Cooking," Cereal Science Today, Vol. 14, 1969, pp. 4-7, 11-12.

[40] R. Mora-Escobedo, O. Paredes-López and G. F. Gutiérrez-López, "Effect of Germination on the Rheological and Functional Properties of Amaranth Seeds," Lebensmmitel Wissenschaft und-Technologie, Vol. 24, 1994, pp. 241-246.

[41] D. A. Vattem and K. Shetty, "Solid-State Production of Phenolic Antioxidants from Cranberry Pomace by Rhizopus oligosporus," Food Biotechnology, Vol. 16, No. 3, 2002, pp. 189-210. doi:10.1081/FBT-120016667

[42] R. Randhir, D. Vattem and K. Shetty, "Solid-State Bioconversion of Faba Bean by Rhizopus oligosporus for Enrichment of Phenolic Antioxidants and L-DOPA," Innovative Food Science and Emerging Technologies, Vol. 5, No. 2, 2004, pp. 235-244. doi:10.1016/j.ifset.2004.01.003

[43] C. H. Lin, Y. T. Wei and C. C. Chou, "Enhanced Antioxidative Activity of Soybean Koji Prepared with Various Filamentous Fungi," Food Microbiology, Vol. 23, No. 7, 2006, pp. 628-633. doi:10.1016/j.fm.2005.12.004

[44] M. Naczk and F. Shahidi, "Phenolics in Cereals, Fruits and Vegetables: Occurrence, Extraction and Analysis," Journal of Pharmaceutical and Biomedical Analysis, Vol. 41, No. 5, 2006, pp. 1523-1542. doi:10.1016/i.jpba.2006.04.002

[45] A. Segev, H. Badani, Y. Kapulnik, I. Shomer, M. OrenShamir and S. Galili, "Determination of Polyphenols, Flavonoids, and Antioxidant Capacity in Colored Chickpea (Cicer arietinum L.)," Journal of Food Science, Vol. 75, No. 2, 2010, pp. S115-S119. doi:10.1111/j.1750-3841.2009.01477.x

[46] Y. Yao, W. Sang, M. Zhou and G. Ren, "Antioxidant and $\alpha$-Glucosidase Inhibition of Colored Grains in China," Journal of Agricultural and Food Chemistry, Vol. 58, No. 2, 2010, pp. 770-774. doi:10.1021/jf903234c

[47] Y. Yao, X. Cheng, L. Wang, S. Wang and G. Ren, "Biological Potential of Sixteen Legumes in China," International Journal of Molecular Science, Vol. 12, No. 10, 2011, pp. 7048-7058. doi:10.3390/ijms12107048

[48] M. J. Heiras-Palazuelos, M. Ochoa-Lugo, S. Mora-Rochin, R. Gutiérrez-Dorado, J. Milan-Carrillo, J. A. GarzónTiznado and C. Reyes-Moreno, "Technological Properties, Antioxidant Activity and Total Phenolic and Flavonoid Content of Pigmented Chickpea (Cicer arietinum L) Cultivars," International Journal of Food Science and Nutrition, Vol. 64, No. 1, 2012, pp. 69-76. doi:10.3109/09637486.2012.694854

[49] R. Randhir and K. Shetty, "Mung Beans Processed by Solid-State Bioconversion Improves Phenolic Content and Functionality Relevant for Diabetes and Ulcer Management," Innovative Food Science and Emerging Technologies, Vol. 8, No. 2, 2007, pp. 197-204. doi:10.1016/j.ifset.2006.10.003

[50] J. G. Torruco-Uco, L. A. Chel-Guerrero, A. MartínezAyala, G. Dávila-Ortíz and D. A. Betancur-Ancona, "Angiotensin-I Converting Enzyme Inhibitory and Antioxidant Activities of Protein Hydrolysates from Phaseolus lunatus and Phaseolus vulgaris Seeds," Food Science and Technology, Vol. 42, No. 10, 2009, pp. 1597-1604.

[51] K. X. Zhu, H. M. Zhou and H. F. Qian, "Antioxidant and Free Radical-Scavenging Activities of Wheat Germ Protein Hydrolysates (WGPH) Prepared with Alcalase," Process Biochemistry, Vol. 41, No. 6, 2006, pp. 1296-1302. doi:10.1016/j.procbio.2005.12.029

[52] C. Silva-Sánchez, A. P. Barba de la Rosa, M. F. LeónGalván, B. O. de Lumen, A. de León-Rodríguez and E. G. de Mejía, "Bioactive Peptides in Amaranth (Amaranthus hypochondriacus) Seed," Journal of Agricultural and Food Chemistry, Vol. 56, No. 4, 2008, pp. 1233-1240. doi:10.1021/jf072911z

[53] M. I. Torino, R. I. Limón, C. Martínez-Villaluenga, S. Mäkinen, A. Pihlanto, C. Vidal-Valverde and J. Frias, "Antioxidant and Antihypertensive Properties of Liquid and Solid State Fermented Lentils," Food Chemistry, Vol. 136, No. 2, 2013, pp. 1030-1037. doi:10.1016/j.foodchem.2012.09.015

[54] L. Chel-Guerrero, M. Domínguez-Magaña, A. MartínezAyala, G. Dávila-Ortiz and D. Betancur-Ancona, "Lima Bean (Phaseolus lunatus) Protein Hydrolysates with ACE-I 
Inhibitory Activity," Food and Nutrition Sciences, Vol. 3, No. 4, 2012, pp. 511-521. doi:10.4236/fns.2012.34072

[55] O. Paredes-López, J. González-Castañeda and A. Cárabez-Trejo, "Influence of Solid Substrate Fermentation on the Chemical Composition of Chickpea," Journal of Fermentation Bioengineering, Vol. 71, No. 1, 1991, pp. 5862. doi:10.1016/0922-338X(91)90304-Y

[56] R. A. Sparringa and J. D. Owens, "Protein Utilization during Soybean Tempe Fermentation," Journal of Agricultural and Food Chemistry, Vol. 47, No. 10, 1999, pp. 4375-4378. doi:10.1021/jf981279u

[57] S. Hendrich, "Battling Obesity with Resistant Starch," Food Technology, Vol. 64, No. 3, 2010, pp. 22-30.

[58] W. Shurtleff and A. Aoyagi, "The Book of Tempeh, a Super Soy from Indonesia," Harper \& Row (Colophon Books), New York, 1979.

[59] L. R. Ferguson, C. Tasman-Jones, H. Englyst and P. J. Har- ris, "Comparative Effects of Three Resistant Starch Preparations on Transit Time and Short-Chain Fatty Acids Production in Rats", Nutrition Cancer, Vol. 36, No. 2, 2000, pp. 230-237. doi:10.1207/S15327914NC3602 13

[60] J. Hasjim and J. L. Jane, "Production of Resistant Starch by Extrusion Cooking of Acid-Modified Nomal-Maize Starch," Journal of Food Science, Vol. 74, No. 7, 2009 , pp. C556-C562. doi:10.1111/j.1750-3841.2009.01285.X

[61] P. I. Angulo-Bejarano, N. M. Verdugo-Montoya, E. O. Cuevas-Rodríguez, J. Milán-Carrillo, R. Mora-Escobedo, J. A. López-Valenzuela, J. A. Garzón-Tiznado and C. Reyes-Moreno, "Tempeh Flour from Chickpea (Cicer arietinum L). Nutritional and Physicochemical Properties," Food Chemistry, Vol. 106, No. 1, 2008, pp. 106-112. doi:10.1016/j.foodchem.2007.05.049

[62] USDA, “Antioxidants and Heatlh," ACES Publications, 2010, p. 4. 